\title{
Religious Perspectives and Cultural Change in PubSlic Life (In the New Normal Covid 19 Era)
}

\author{
$1^{\text {st }}$ Siti Ummi Masruroh ${ }^{1}, 2^{\text {nd }}$ Arif Zamhari $^{2}, 3^{\text {rd }}$ Muhammad Sunandar Alwi $^{3}$, \\ $4^{\text {th }}$ Kamarusdiana $^{4}, 5^{\text {th }}$ Syifa Anggia Priantika ${ }^{5}, 6^{\text {th }}$ Dewi Aprilia Ningrum ${ }^{6}, 7^{\text {th }}$ \\ Alvin Noor Sahab ${ }^{7}$ \\ \{ ummi.masruroh@uinjkt.ac.id ${ }^{1}$, arif.zamhari@uinjkt.ac.id ${ }^{2}$, muhammadsunandaralwi@live.undip.ac.id ${ }^{3}$, \\ kamarusdiana@uinjkt.ac.id ${ }^{4}$, syifaAnggiaPriantika@gmail.com ${ }^{5}$, \\ dewi.ap rilianingrum18@mhs.uinjkt.ac.id ${ }^{6}$, alvin.noor18@mhs.uinjkt.ac.id $\left.{ }^{7}\right\}$ \\ Sy arif Hiday atullah State Islamic University of Jakarta, Indonesia ${ }^{1,2,4,5,6,7}$ \\ Diponegoro University, Semarang, Indonesia ${ }^{3}$
}

\begin{abstract}
Socio-cultural changes are a sign of changes in social structure and cultural patterns in society. Socio-cultural change is a common symptom that occurs and always occurs in every society. These changes are based on the nature and nature of humans who always want to make changes. Covid-19 pandemic has changed all aspects of our daily lives. The an xiety and insecurity experienced by most of us must be handled fairly so that we can survive and help others to survive. We must also practice a healthy lifestyle and follow government recommendations to prevent the spread of Covid-19.
\end{abstract}

Keywords: Religious, Cultural, New Normal Covid 19

\section{Introduction}

The outbreak of a new virus is a new type of coronavirus (SARS-CoV2) and the disease is called Coronavirus disease 2019 (Covid-19). It is known that the origin of this virus came from Wuhan, China. Found at the end of December 2019. Corona virus is a type of virus that can be transmitted through air, water, objects, disease factors, and can be transmitted throu gh droplets (droplets of saliva). In this case, environmental factors play a very important role. Human interaction with the environment has led to contact between germs, viruses, and bacteria with humans. This is an extraordinary phenomenon that occurs on earth in the $21 \mathrm{st}$ century.

Infectious diseases have existed since ancient times, there are several infectious diseases, Information is available about diseases in Southeast Asia before the 16th century. In the Bumiputera texts, the existing references are from later times, and this indicates that smallpox and other destructive diseases of the body - leprosy and pile or syphilis are most feared. The 17th-century account of the founding of Ayutthaya in the 14th century mentions the promise that the city would be free of smallpox, but also mentions that the plague killed everyone who tried to live there before the surrounding marshes were closed (indicating malaria).[1]

The rapid spread of the Covid-19 virus by preventing contagious is difficult for even developed countries (Nugraha, 2020). In Indonesia, with a large area and there are still remote residents, it has its difficulties to mitigate the Covid-19 pandemic. This does not mean that 
there will be no more viruses or pandemics. The world's population will decline drastically as a result, deadly a virus above. Social, cultural, and economic lifestyles also change. Cultural changes occur in society during this pandemic. Because life is dynamic so that every life is always changing so that humans will experience changes, both as individuals and as a society. In the changes that occur in society (as a collection of individuals), it can occur in individual or organizational behavior patterns, in social norms, and also includes their interactions.

So, what is the relationship between religion and the socio-cultural changes of society in the new normal era with the Covid-19 pandemic? The history of pandemics has often produced narratives that describe the attitudes and behavior of religious communities in the face of disasters. The government's current efforts through various ministries and institutions, as well as actions taken by all parties to overcome the impact of the Covid-19 outbreak according to WHO world health standards. So that narratives and actions carried out in the name of religion can work in harmony without contradicting logic and education provided by the experts.

\section{Research methods}

The research method used is descriptive qualitative with a phenomenological approach. The phenomenological approach tries to explain or reveal the meaning of the concept or phenomenon of experience which is based on the awareness that occurs in some individuals. This research was conducted in a natural situation so that there are no limitations in interpreting or understanding the phenomenon being studied.[2] That said, the phenomenological approach suspends all judgments about natural attitudes until some basis is found. This delay is usually called the period. This concept is to differentiate the subject area from the researcher's interpretation. This concept is central to where researchers compile and classify initial assumptions about phenomena to understand data. Furthermore, the researcher conducted data analysis which was an effort to systematically find and organize notes on the results of observations and others to increase the researchers' understanding of the cases being studied and present them as findings to others. As for increasing this understanding, the analysis needs to be continued by trying to find meaning. The data that has been collected will provide a clearer picture and make it easier for researchers to carry out further data collection, and search for it if necessary. Also, in certain social situations, researchers in reducing data may focus on religious perspectives, cultural changes in people's lives in the new normal Covid-19 era.[3]

\section{Results and Discussion}

In community life, aspects of religion and culture are related to one another. Religion is a guideline for human life created by God, in living their life. Meanwhile, culture is a habit of the way of life of humans which was created by humans themselves from the results of their creativity, taste, and character given by God.[4] Humans are cultured creatures, through their intellect humans can develop culture, so humans live and depend on culture as a result of their creation. Culture also provides rules for humans in managing the environment with the technology it creates. There is a process of shifting society and culture known as social dynamics. Some of the important concepts on this issue are internalization, diffusion, 
acculturation and assimilation, and innovation.[5] Religion and culture influence each other, religion affects culture, community groups, and ethnic groups. Culture tends to fluctuate, which means an unstable condition or condition, which shows symptoms that are not fixed and always changing so that the authenticity of religion has led to different interpretations. Because religion is a certain belief that is held by most people, it is a life guide. Religion concerns beliefs and their various practices and is a social problem that is currently found in every society.

In society, change is largely due to how information is transmitted, with people who are always connected and constantly informed about what's happening in someone's life or what's happening around the world.[6] The term new normal focuses more on cultural changes in society to have a healthy lifestyle. New normal is a culture change. For example, always apply a clean and healthy lifestyle (PHBS), wear a mask if you want to leave the house, wash your hands, maintain social distancing.

According to the large Indonesian dictionary, change means a changing situation, transition, exchange, and many things will change. Socialis $m$ is a problem related to society. Social change is a change in the social structure or community structure of a society. These changes are common symptoms that occur over time. In every social order, change also occurs according to its characteristics. Basic human beings who always want to change from one state to another. Pudjiwati Sajagyo cites Hirschman as boring. Humans are the cause of change. People are usually dissatisfied and bored. A situation and trying to find a way or other way to get rid of it. Bored and looking for new ways that are more fun, easy, and cheap. We can see that the transportation technology revolution is so complex that there are consequences regarding changes in human mobility. Social and cultural changes are signs of changing social structures and patterns.[7]

Socio-cultural change is a common phenomenon, occurring all the time in every society. Change occurs based on the nature and nature of humans who always want to make changes. Hirschman says that human boredom is the cause of change. Socio-cultural changes are caused by many factors. Including communication; people's methods and mindsets; other internal factors, such as demographic changes, discoveries, conflicts or revolutions, and external factors such as natural disasters and climate change, wars, and the cultural influence of others.

The scope of social change includes immaterial material and cultural factors, meaning that every socio-cultural element is material and immaterial (mental) also tends to change. Contrary to what Kingsley Dav is said, defining social change occurs in the order and function of society, so it is called social change. The order and functions of society are changing, for example when labor unions or labor organizations emerge in a capitalist society. Changes in the relationship between workers and employers, which will result in economic organization and even political change (in some countries, there have been changes to political parties, such as the Labor Party in Britain).

Soerjono Soekanto[8] cites the view in his book sociology as an introduction by quoting Gillin about social change as a change in lifestyle. Due to changes in conditions that already exist and are accepted by the community. either because of changes in geography, material culture, population composition, ideology, or because of its spread and the latest technological discoveries. Therefore, if society holds or changes. Another way of existing habits is called change.

From a religious perspective, the concept of social change is a complex phenomenon in all aspects of social life. If there is a definition of social change covering all aspects of social life, it is so natural that it occurs in the social structure, social system, and social organization of 
society. From this perspective, it can be said that social change is a change in the structure and function of the social system including in terms of culture, values, norms, habits, beliefs, traditions, attitudes, and social behavior. Compare the differences in current social conditions with the past, it can be said that the social structure of society has changed.

Social change is a response from the community whether consciously or not as an effort to adapt (adaptation) to the conditions that occur around them. Changes to the new normal behavior are not easy to implement. In several community groups, it is not uncommon to find violations of health protocols in carrying out daily activities whether they are aware of it or not. Therefore, one of the effective strategies to make these changes quickly internalized in each society is the revolution mechanis $m$. To realize a new normal behavior change that takes place quickly (revolution), sociologically it requires the role of a leader who has power and influence on members of the community. The leader can be a formal or informal figure.

In early 2020, humanity around the world was shaken by the Corona Virus (Covid-19) pandemic which caused panic everywhere. Hundreds of thousands of people were infected and thousands more died. In Indonesia itself, the government has given appeals to the public in overcoming this epidemic so that it runs effectively and efficiently. But in reality, there are still many Indonesians who do not heed this appeal.[9]

The more widespread the epidemic and the significant impact of this virus in aspects of the life of the Indonesian people, keeping mental health in prime condition is a must. Mentally healthy will make life satisfaction which is closely related to happiness where happy people will have a high immune system so they can ward off the virus outbreak. Facing Corona, religious experts need to work more closely with medical and health experts so that people believe that history has proven that the pandemic cannot identify religion, race, age, gender, and social class. He didn't choose, he didn't choose. He was going to attack everyone, so he had to co me face to face. The government has decided that Indonesia will experience an emergency disaster due to corona. Even though we all know that it does not mean stopping worship, religious communities have carried out ijtihad to postpone religious ceremonies.

Allah SWT commands us to eat when we are hungry, drink when we are thirsty, look for med icine when we are sick, and pay attention to everything that can cause us illness, including staying alert and try ing to overcome the COVID19 outbreak. Then Allah also commands us to know through science that no one can do anything except Allah and has no other influence except sunnatullah. We are also instructed to believe that Allah has created everything and ordered everything in nature to carry out their duties according to the task entrusted as $\mathrm{He}$ said: "You know, he only belongs to all creatures and all affairs". (Surah Al-A'raaf: 54). Social change due to Covid-19 is part of sunnatullah, and we as living beings cannot avoid sunnatullah this. Before us, there are at least three things to do.[10]

First, do our best to study sunnatullah or natural law through science or technology so that we can discover the secrets behind Covid-19 and respond positively to all the changes it brings. Do not let this corona virus cause other, more dangerous viruses, such as moral decadence and the loss of religious values in social life.

Second, we as Muslims (people who obey the power of Allah) must adhere to the belief that there is a system (law) that does not apply to the human will in this life so that in all these efforts there is always a return to Allah SWT.

With effort and tawakal as exemplified by the prophet Yusuf AS when teaching the Egyptians to face the dry season. Yusuf AS knows that the Egyptian people will face difficult times for seven years. This difficult time is a life cycle that cannot be avoided, so the prophet Yusuf taught them to grow crops and harvest for seven years, it turns out that the hard times have 
arrived so that the food reserves that have been stored for seven years can be used to cover it. Food needs in those difficult times. (QS Yusuf: 43-49).

Third, study Covid-19 wisely. When the Corona virus appeared, the government then appealed not to leave the house. Many people are shocked and do not want to accept this fact because they cannot support their families, cannot worship, as usual, lecturers/teachers cannot face every student. And can not interact socially as usual. Several people/members of the community gradually realized the lessons from this situation Covid-19. That people need masks in sufficient quantities to be used and become a new market share.

The cultural pattern of society changes, adapting to the health protocol recommended by the government. For example, when leaving the house, you have to wear masks, not crowd, and always maintain social distancing, increase the use of digital technology, increase the standard of human health and comfort in buildings/houses, encourage the ease and speed of online licensing services, prioritize occupational health and safety, increase effectiveness work and employee productivity while paying attention to health protocols. Activities tend to be conducted online, virtual, and distance learning.

Muslims cannot worship in mosques in the red zone if they must comply with health protocols by keeping a distance. Lecturers/teachers cannot meet their students directly so that they can motivate them to become more proficient in using IT as a medium of learning. The public cannot communicate directly with each other in meetings, scientific events, and other activities, but can communicate via Zoom, Google Hangouts Meet, Cisco Webex, etc.

People will adapt themselves to the environment using culture. The habits that exist in a particular society are an adjustment of that society to its environment. But that one mode of adjustment does not represent all possible ways of adjustment. Different human societies may choose different ways of adapting to the same situation. If you want to take a closer look, Arab sources have a good record of the reaction of the Prophet Muhammad and his companions to this plague. The prophets and saints then did not oppose the plague in the name of Tawhid or act recklessly in the name of "only fearing Allah". They have a motive to teach that the essence of religion is to protect humans, and Is lamic religious organizations (maqasid syari'ah are hifzal-nafs) is the real tawhid.[11]

People's culture can also be said to have changed for the worse, it can be said that in this new normal era some people still work from home, education is also held by learning at home. However, there are still many obstacles and limitations, people who carry out learning and working at home tend to be more relaxed and less productive. Some even claim to have lost their sanity during this time of the pandemic. On the other hand, many find their inner calling to be teachers, doctors, cooks in their homes, these things are difficult for some people to do at the same time.

Of course, this social change must be carried out gradually and requires a lot of time, because it is related to changes in values, culture, and community behavior. We hope to survive the post-Covid-19 period smoothly without harming society, religion, and the country.

\section{Conclusion}

Re ligion, culture, and society are interrelated. Relation of religion, culture, and society, as well as religion, acts as a means of control, as well as civilizing it in the sense of expressing people's beliefs in cultural forms. Religion is a cultural concept and cultural reality in Indonesia. Culture is the result of the interaction between humans and everything in this 
universe. Humans can create a culture through their ability to think. Culture is used to understand religion that appears in a formal form that is prevalent in society. Changes that occur in society are of course very influential on people's lives. All of the social problems that arise in society are also experienced by them. The direct and indirect impacts of the covid-19 pandemic are felt by the community. Because at this time in the new normal era, society is experiencing changes for the better and vice versa. However, there are still many obstacles and limitations, people who carry out learning and working at home tend to be more relaxed and less productive. So that the community plays its role to help prevent the transmission of the Covid-19 outbreak. With health protocols in all aspects of social life, relig ion, and others. So that the community plays a role in better socio-cultural change. 


\section{References}

[1] A. Reid, Asia Tenggara Dalam Kurun Niaga 1450-1680 Jilid 2: Jaringan Perdagangan Global. Yay asan Pustaka Obor Indonesia, 2011.

[2] T. Groenewald, "A phenomenological research design illustrated," Int. J. Qual. methods, vol. 3, no. 1, pp. 42-55, 2004.

[3] N. Muhadjir, "Metodologi Penelitian Kualitatif, Rake Sarasin.” Yogy akarta, 2002.

[4] L. M. Bauto, "Perspektif Agama Dan Kebudayaan Dalam Kehidupan Masyarakat Indonesia," J. Pendidik. Ilmu Sosia, vol. 23, 2014.

[5] I. Subchi, "Pengantar antropologi." LP2M UIN Jakarta Press, 2016.

[6] M. B. T. Sampurno, T. C. Kusumandy oko, and M. A. Islam, "Buday a Media Sosial, Edukasi Masy arakat, Dan Pandemi COVID-19,” SALAM J. Sos. dan Budaya Syar-i, vol. 7, no. 5, 2020.

[7] S. Sy amsidar, "DAMPAK PERUBAHAN SOSIAL BUDAYA TERHADAP PENDIDIKAN," Al-Irsyad Al-Nafs J. Bimbing. dan Penyul. Islam, vol. 2, no. 1, 2015.

[8] S. Soekanto and S. S. Pengantar, "Jakarta: PT Raja Grafindo Persada, 2003) Cet," Ke-35.

[9] D. Riksa Buana, "Analisis Perilaku Masyarakat Indonesia dalam Menghadapi Pandemi Virus Corona (Covid-19) dan Kiat Menjaga Kesejahteraan Jiwa,” Journal. Uinjkt. Ac. Id, 2020.

[10] Ma. Prof Dr Syihabuddin Qalyubi, Lc, "3 Tawaran Sikap Qurani Hadapi Perubahan Sosial Covid-19," Republika.co.id, vol. 7, no. 9, 2020.

[11] Oman Fathurahman, "Sejarah Wabah Pandemi dan Narasi Agama-Agama," Alif.id, 2020. 